\title{
Plant leaves for wrapping zongzi in China: an ethnobotanical study
}

Fengke Lin ${ }^{1,2}$, Binsheng Luo ${ }^{1,2}$, Bo Long $^{3 *}$ and Chunlin Long ${ }^{1,2,4^{*}}$ (D)

\begin{abstract}
Background: Zongzi, a common Chinese rice-pudding and one of the most symbolic foods in traditional Chinese festivals, is integral to both Chinese traditional culture and daily meals. Traditionally, the leaves of different plant species have been used to wrap zongzi. The variety of zongzi leaves (ZLs) can contribute to the zongzi-based cultural diversity. Given the cultural and dietary significance of zongzi, the ethnobotanical surveys were carried out, aiming to investigate the diversity of plant species and associated traditional botanical knowledge of ZLs, which could attract particular attention for their further studies.

Method: Both literature studies and field surveys were conducted in the study. The field investigations were carried out from May 2006 to June 2018 throughout China. Ethnobotanical information about ZLs was obtained by direct observation, semi-structured interviews, and key informant interviews.

Results: In total, ZLs from 57 plant species were identified and recorded, belonging to 38 genera and 18 families. Several folk legends have been formed to explain the origin of using plant leaves to pack zongzi. Over time, Chinese people have developed diverse traditional botanical knowledge surrounding ZLs, especially regarding the zongzi flavor, antiseptic functions, and medicinal values. Based on the literature review, some species of ZLs such as the leaves of Corchorus capsularis and Vernicia fordii may even pose a potential threat to human health. Presently, in some regions of China, the traditional ZLs, such as Cocos nucifera, Tilia tuan, and Zizania latifolia, are being substituted by commercialized ZLs such as Phragmites australis and Indocalamus tessellatus.

Conclusion: A variety of traditional ZLs have been discovered in China. Although diverse traditional knowledge exists in China surrounding the usage of ZLs, some species may have the potential of threatening human health. Therefore, further explorations are necessary to comprehensively evaluate traditional ZLs, the results of which could help to conserve the cultural diversity of zongzi, to guarantee food safety, and to encourage the uses of plant leaves in food, medicine, and environmental management, for our human health.
\end{abstract}

Keywords: Plant leaves, zongzi, Dragon Boat Festival, Traditional botanical knowledge, Chinese symbolic food

\section{Background}

The Dragon Boat Festival, one of the most significant traditional festivals in China, has been celebrated for over 2000 years, occurring on the fifth day of the fifth month in the Chinese lunar calendar [1]. It is also named the Zongzi Festival, since eating zongzi is a widespread custom to celebrate this festival all over China [2]. Zongzi, also named Jiao Shu and Tong Zong, is a

\footnotetext{
*Correspondence: longbo@ynu.edu.cn; long@mail.kib.ac.cn; long.chunlin@muc.edu.cn

${ }^{3}$ School of Life Science, Yunnan University, Kunming 650091, China

${ }^{1}$ Key Laboratory of Ethnomedicine (Minzu University of China), Ministry of

Education, Beijing 100081, China

Full list of author information is available at the end of the article
}

traditional Chinese rice-pudding, which is made of glutinous rice stuffed with different fillings, and then wrapped in plant leaves that are used only for wrapping purposes instead of consumption. Additionally, zongzi also plays an indispensable role in daily meals in China [2]. Even though zongzi has a distinct cultural significance for Chinese people, zongzi-like food is prevalent and carries cultural significance in many other countries and regions, such as Japan, Korea, the Philippines, and Latin America. In Japan, the zongzi-like food called Chimaki is made of rice flour and is also essential to the Dragon Boat Festival, while in Mexico, tamales is made of maize-based dough to celebrate Day of the Dead [3,

(c) The Author(s). 2019 Open Access This article is distributed under the terms of the Creative Commons Attribution 4.0 International License (http://creativecommons.org/licenses/by/4.0/), which permits unrestricted use, distribution, and 
4]. In Southeast and East Europe, sarma or dolma, usually made of rice, bulgur, or minced meat and wrapped in plant leaves, are very common. In Turkey and Caucasus, these foods could be served as festivity meals to celebrate some festivals, such as Easter and Christmas Eve [5].

In present-day China, a great variety of zongzi has been developed, with different colors, shapes, fillings, and tastes, thus contributing to the diversification of the zongzi culture [6]. There are two most common shapes of zongzi: triangular-pyramidal and rectangular. According to the flavor, zongzi can be roughly divided into three categories: original, salty, and sweet. The original $z o n g z i$ are only made of white glutinous rice without any other salty or sweet ingredients, while the salty and sweet zongzi are made of glutinous rice with the addition of other salty or sweet ingredients. The ingredients added to zongzi vary from region to region [7]. In addition to meat like pork and chicken, different parts of plants have been developed to be used as seasonings, such as the flowers of Nelumbo nucifera, the fruits of Ziziphus jujuba, the seeds of Castanea mollissima, and the leaves of Clausena lansium and Perilla frutescens [6].

Regardless of the category of zongzi, after all the fillings are completely prepared, zongzi is traditionally wrapped by plant leaves of different species called zongzi leaves (ZLs) before they are steamed or boiled. The species of ZLs used depends on regional traditions and geographical locations $[6,8]$. The ideal ZLs should meet the requirements of non-contamination, integrity, proper size, pleasant fragrance, preferable flexibility, and tolerance to steaming or boiling $[8,9]$. These leaves can be collected from the wild and sold on the market immediately. However, commercially, they are usually air-dried for dehydration in long-term storage in order to eliminate the limitation of regionalism and seasonality [10].

In recent years, the development of biodegradable packaging materials for food has received increased attention since petroleum-based plastics have caused serious environmental contamination because of the resistance to degradation [11]. Renewable natural resources can be effective for the development of biodegradable packing materials [12]. Thus, ZLs with packaging functions may provide a new opportunity for the development and utilization of environmentally friendly packaging materials. In addition to the importance of their packaging properties, ZLs can contribute to the flavor and storage time of zongzi. It was reported by Maite et al. [4] that the flavor of tamales, the zongzi-like food from Mexico, was affected by the plant leaves used to wrap them.

Ethnobotanical surveys focusing on the plant leaves used as wrapping materials for food have been reported in some countries and regions [4, 5, 13]. For example, 21 species of plant leaves have been reported to wrap tamales in the Mexican state of Veracruz [4], and the leaves from 87 botanical taxa were used to wrap sarma in Turkey and the Balkans [5]. In addition, plant leaves used to wrap food were discovered from time to time when researchers conducted ethnobotanical investigations [14-18]. For instance, nine species of plant leaves were used to wrap food like tamales which were cooked in earth ovens located in Maya Lowlands [18]. Although a few species of ZLs have been sporadically reported in publications, most of them were published in Chinese $[6,9,10,19]$. No studies, to the best of our knowledge, have been carried out to investigate the ethnobotanical importance of ZLs in China. In view of the cultural and dietary significance of zongzi, the ethnobotanical surveys of ZLs were conducted from May 2006 to June 2018. The aim of the present study was to investigate the plant species and associated traditional knowledge of ZLs, which could help with the conservation of the cultural diversity of zongzi, and be of interest to scientific researchers studying the traditional uses of ZLs. If the associated traditional knowledge can be recorded and understood, it would make contributions to food safety and to the further development and utilization of ZLs in the fields of food, medicine, environmental sanitation, and more broadly, for the sake of our human and environmental health.

\section{Materials and methods \\ Literature studies}

A large quantity of records about zongzi has been discovered in ancient literatures. Collections from the $\mathrm{Na}$ tional Library of China, together with books from ancient to recent times were investigated and examined. Information on the plant species recorded in Flora of China (English version) has been intensively studied. In addition, information from databases including Web of Science (WoS), Science Direct, Google Scholar, PubMed, and the Chinese databases such as WP (China Science and Technology Journal Database), Wanfang and CNKI (China National Knowledge Infrastructure) were used in the study.

\section{Field surveys}

Our research group has focused on the ZLs for a long time. Here, we recorded and summarized all the ethnobotanical surveys concerning the ZLs by our group. The surveys were mainly conducted close to the Dragon Boat Festival because the zongzi were prevalent during this festival, which was beneficial for us to identify the species of ZLs and to investigate the associated traditional knowledge. The ethnobotanical investigations of ZLs were conducted on 31 separate occasions throughout China from May 2006 to June 2018, including 23 provinces, 5 autonomous regions, 4 municipalities, and 2 
special administrative regions. Two to nine areas (county or county-level city/district) were investigated in each province. In total, 143 areas throughout China were studied (Fig. 1). In each area, 2 to 5 villages were surveyed and 5-10 people in each village who had traditional knowledge of ZLs were chosen to interview. A total of 3603 informants including 1701 males and 1902 females between 18 and 87 years of age were interviewed. Informants could be characterized as belonging to the following ethnic groups: Mongolian, Tibetan, Uygur, Hui, Miao, Yi, Zhuang, Buyi, Man, Korean, Dong, Bai, Yao, Hani, Tujia, Dai, Li, She, Shui, Qiang, Maonan, Lisu, Jinuo, and Gaoshan ethnic groups, as well as the Han people, who represent the major linguistic group in China.

Several different ethnobotanical methods, including direct observation, semi-structured interviews, and key informant interviews [20] were employed to collect the ethnobotanical data. When conducting surveys, we strictly followed the ethical guidelines issued by the American Anthropological Association (www.aaanet.org) and the International Society of Ethnobiology (http:// www.ethnobiology.net). During our surveys, the scientific name, family name, Chinese name, life form, medicinal value, and main distribution of ZLs were recorded. Voucher specimens collected from the various regions were determined and identified by the authors based on Flora of China (http://flora.huh.harvard.edu/ china), and the nomenclature standards of plant species were referred to The Plant List (http://www.theplantlist. org/). The voucher specimens were deposited in the Herbarium of the Minzu University of China.

\section{Results and discussion}

\section{Diversity of plant leaves used for zongzi-wrapping}

China harbors great plant biodiversity, with about 34, 000 species of higher plants discovered and recorded [21]. With such diverse plant resources, people in different regions of China have generated different traditions to use local plant species to wrap zongzi. On the basis of investigations in China, a total of 57 plant species were documented and identified, falling into 38 genera and 18 families (Table 1). Some examples of zongzi with different shapes wrapped by plant leaves are shown in Figs. 2 and 3. There was only one species, namely, Podocarpus nagi, that belonged to gymnosperm, while others were all categorized into angiosperm (Table 1). Among the

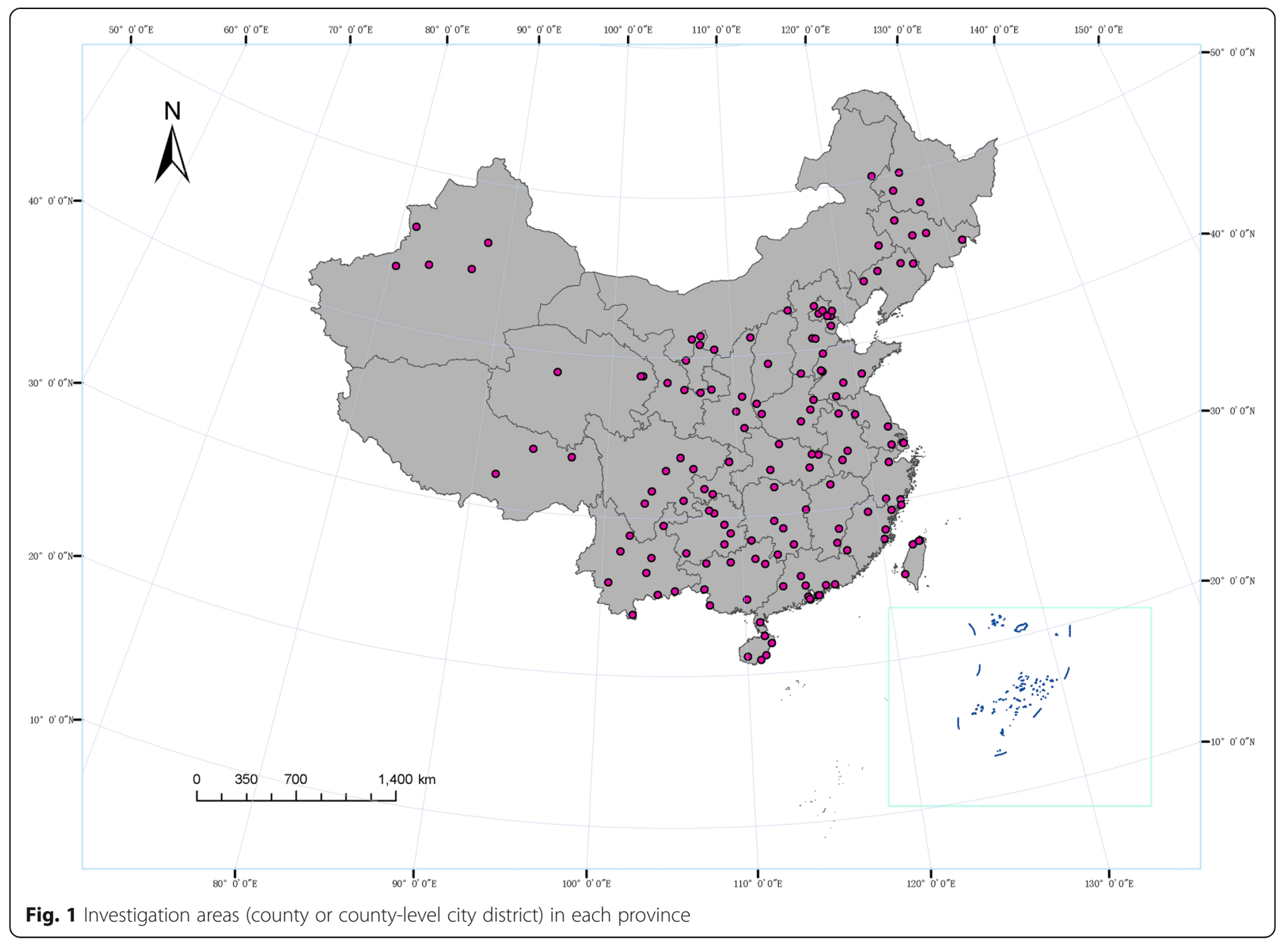


Table 1 Plant leaves used to wrap zongzi in China based on our field work

\begin{tabular}{|c|c|c|c|c|c|c|c|}
\hline No. & Scientific name & Family name & $\begin{array}{l}\text { Chinese } \\
\text { name }\end{array}$ & $\begin{array}{l}\text { Life } \\
\text { form }\end{array}$ & Medicinal value & Main distribution & $\begin{array}{l}\text { Voucher } \\
\text { number }\end{array}$ \\
\hline 1 & $\begin{array}{l}\text { Alpinia abundiflora Burtt } \\
\text { and R. M. Sm. }\end{array}$ & Zingiberaceae & 草豆冦 & Herb & $\begin{array}{l}\text { Treating rheumatism, invigorating spleen and } \\
\text { alleviating emesis }\end{array}$ & Hainan & $\begin{array}{l}\text { MUCH- } \\
\text { ZLs-057 }\end{array}$ \\
\hline 2 & Alpinia pricei Hayata & Zingiberaceae & $\begin{array}{l}\text { 短穗山 } \\
\text { 姜 }\end{array}$ & Herb & - - & Taiwan & $\begin{array}{l}\text { MUCH- } \\
\text { ZLs-046 }\end{array}$ \\
\hline 3 & $\begin{array}{l}\text { Alpinia zerumbet (Pers.) B. } \\
\text { L. Burtt and R. M. Sm. }\end{array}$ & Zingiberaceae & 艳山姜 & Herb & Treating rheumatism & Taiwan and Fujian & $\begin{array}{l}\text { MUCH- } \\
\text { ZLs-039 }\end{array}$ \\
\hline 4 & Amomum villosum Lour. & Zingiberaceae & 砂仁 & Herb & Treating rheumatism & $\begin{array}{l}\text { Guangdong, } \\
\text { Guangxi, } \\
\text { Yunnan }\end{array}$ & $\begin{array}{l}\text { MUCH- } \\
\text { ZLs-010 }\end{array}$ \\
\hline 5 & Arundo donax $\mathrm{L}$. & Gramineae & 芦竹 & Bamboo & Clearing heat and diuresis & $\begin{array}{l}\text { Yunnan, Guangxi, } \\
\text { and Guizhou }\end{array}$ & $\begin{array}{l}\text { MUCH- } \\
\text { ZLs-007 }\end{array}$ \\
\hline 6 & Aspidistra elatior Blume & Liliaceae & $\begin{array}{l}\text { 蜘蛛抱 } \\
\text { 蛋 }\end{array}$ & Herb & $\begin{array}{l}\text { Diminishing inflammation, hemostasis, treating } \\
\text { rheumatism and analgesia }\end{array}$ & $\begin{array}{l}\text { Yunnan and } \\
\text { Guizhou }\end{array}$ & $\begin{array}{l}\text { MUCH- } \\
\text { ZLs-008 }\end{array}$ \\
\hline 7 & $\begin{array}{l}\text { Aspidistra oblanceifolia } \mathrm{F} \text {. } \\
\text { T. Wang et K. Y. Lang }\end{array}$ & Liliaceae & 棕叶草 & Herb & - - & $\begin{array}{l}\text { Yunnan and } \\
\text { Guizhou }\end{array}$ & $\begin{array}{l}\text { MUCH- } \\
\text { ZLs-044 }\end{array}$ \\
\hline 8 & $\begin{array}{l}\text { Aspidistra sichuanensis K. Y. } \\
\text { Lang et Z. Y. Zhu }\end{array}$ & Liliaceae & $\begin{array}{l}\text { 四川蜘 } \\
\text { 蛛抱蛋 }\end{array}$ & Herb & - - & $\begin{array}{l}\text { Sichuan, Yunnan, } \\
\text { and Guizhou }\end{array}$ & $\begin{array}{l}\text { MUCH- } \\
\text { ZLs-043 }\end{array}$ \\
\hline 9 & $\begin{array}{l}\text { Aspidistra zongbayi K. Y. } \\
\text { Lang et Z. Y. Zhu }\end{array}$ & Liliaceae & 粽粑叶 & Herb & $\begin{array}{l}\text { Clearing heat, detoxification, hemostasis, and } \\
\text { diuresis }\end{array}$ & $\begin{array}{l}\text { Yunnan and } \\
\text { Guizhou }\end{array}$ & $\begin{array}{l}\text { MUCH- } \\
\text { ZLs-009 }\end{array}$ \\
\hline 10 & Cocos nucifera $\mathrm{L}$. & Palmae & 椰子 & Tree & Clearing heat & Hainan & $\begin{array}{l}\text { MUCH- } \\
\text { ZLs-031 }\end{array}$ \\
\hline 11 & Corchorus capsularis L. & Tiliaceae & 黄麻 & Herb & $\begin{array}{l}\text { Diminishing inflammation, detoxification, } \\
\text { hemostasis, and analgesia }\end{array}$ & Guangxi & $\begin{array}{l}\text { MUCH- } \\
\text { ZLs-034 }\end{array}$ \\
\hline 12 & $\begin{array}{l}\text { Dendrocalamus giganteus } \\
\text { Munro }\end{array}$ & Gramineae & 龙竹 & Bamboo & Clearing heat & Yunnan & $\begin{array}{l}\text { MUCH- } \\
\text { ZLs-011 }\end{array}$ \\
\hline 13 & $\begin{array}{l}\text { Dendrocalamus latiflorus } \\
\text { Munro }\end{array}$ & Gramineae & 麻竹 & Bamboo & Clearing heat and detoxification & Southern China & $\begin{array}{l}\text { MUCH- } \\
\text { ZLs-056 }\end{array}$ \\
\hline 14 & $\begin{array}{l}\text { Evodia glabrifolia (Champ.) } \\
\text { N. P. Balakr. }\end{array}$ & Rutaceae & $\begin{array}{l}\text { 楝叶吴 } \\
\text { 莫 }\end{array}$ & Tree & Diminishing inflammation and analgesia & $\begin{array}{l}\text { Guangxi, Hainan } \\
\text { and Fujian }\end{array}$ & $\begin{array}{l}\text { MUCH- } \\
\text { ZLs-032 }\end{array}$ \\
\hline 15 & Fargesia fractiflexa T.P. Yi & Gramineae & 扫把竹 & Bamboo & -— & Yunnan & $\begin{array}{l}\text { MUCH- } \\
\text { ZLs-012 }\end{array}$ \\
\hline 16 & $\begin{array}{l}\text { Firmiana platanifolia (L.f.) } \\
\text { Marsili }\end{array}$ & Labiatae & 梧桐 & Tree & Clearing heat and detoxification & $\begin{array}{l}\text { Guangdong and } \\
\text { Hunan }\end{array}$ & $\begin{array}{l}\text { MUCH- } \\
\text { ZLs-041 }\end{array}$ \\
\hline 17 & $\begin{array}{l}\text { Hedychium coronarium J. } \\
\text { Koenig }\end{array}$ & Zingiberaceae & 姜花 & Herb & Treating rheumatism, analgesia and insomnia & Taiwan & $\begin{array}{l}\text { MUCH- } \\
\text { ZLs-049 }\end{array}$ \\
\hline 18 & $\begin{array}{l}\text { Indocalamus } \\
\text { guangdongensis H. R. } \\
\text { Zhao and Y. L.Yang }\end{array}$ & Gramineae & $\begin{array}{l}\text { 广东箬 } \\
\text { 竹 }\end{array}$ & Bamboo & Clearing heat and detoxification & $\begin{array}{l}\text { Guangdong, } \\
\text { Guangxi, and } \\
\text { Guizhou }\end{array}$ & $\begin{array}{l}\text { MUCH- } \\
\text { ZLs-020 }\end{array}$ \\
\hline 19 & $\begin{array}{l}\text { Indocalamus herklotsii } \\
\text { McClure }\end{array}$ & Gramineae & $\begin{array}{l}\text { 粽巴箬 } \\
\text { 竹 }\end{array}$ & Bamboo & Clearing heat and detoxification & $\begin{array}{l}\text { Guangdong, } \\
\text { Guangxi } \\
\text { and Hunan }\end{array}$ & $\begin{array}{l}\text { MUCH- } \\
\text { ZLs-037 }\end{array}$ \\
\hline 20 & $\begin{array}{l}\text { Indocalamus latifolius } \\
\text { (Keng) McClure }\end{array}$ & Gramineae & $\begin{array}{l}\text { 阔叶箬 } \\
\text { 竹 }\end{array}$ & Bamboo & Clearing heat and detoxification & Southern China & $\begin{array}{l}\text { MUCH- } \\
\text { ZLs-013 }\end{array}$ \\
\hline 21 & $\begin{array}{l}\text { Indocalamus tessellatus } \\
\text { (Munro) Keng } \mathrm{f} \text {. }\end{array}$ & Gramineae & 箬竹 & Bamboo & $\begin{array}{l}\text { Clearing heat, detoxification, hemostasis, and } \\
\text { diminishing inflammation }\end{array}$ & Southern China & $\begin{array}{l}\text { MUCH- } \\
\text { ZLs-006 }\end{array}$ \\
\hline 22 & $\begin{array}{l}\text { Livistona chinensis (Jacq.) } \\
\text { R.Br. ex Mart. }\end{array}$ & Palmae & 蒲葵 & Tree & Diminishing inflammation and hemostasis & $\begin{array}{l}\text { Yunnan and } \\
\text { Hainan }\end{array}$ & $\begin{array}{l}\text { MUCH- } \\
\text { ZLs-014 }\end{array}$ \\
\hline 23 & $\begin{array}{l}\text { Magnolia officinalis Rehder } \\
\text { and E.H.Wilson }\end{array}$ & Magnoliaceae & $\begin{array}{l}\text { 凹叶厚 } \\
\text { 朴 }\end{array}$ & Tree & $\begin{array}{l}\text { Treating rheumatism, diminishing } \\
\text { inflammation and analgesia }\end{array}$ & Guangxi & $\begin{array}{l}\text { MUCH- } \\
\text { ZLs-033 }\end{array}$ \\
\hline 24 & $\begin{array}{l}\text { Miscanthus floridulus } \\
\text { (Labill.) Warb. ex K. Schum. } \\
\text { and Lauterb. }\end{array}$ & Gramineae & 五节芒 & Herb & Clearing heat, detoxification, and diuresis & $\begin{array}{l}\text { Fujian and } \\
\text { Zhejiang }\end{array}$ & $\begin{array}{l}\text { MUCH- } \\
\text { ZLs-028 }\end{array}$ \\
\hline 25 & $\begin{array}{l}\text { Monocladus amplexicaulis } \\
\text { Chia et al. }\end{array}$ & Gramineae & 芸香竹 & Bamboo & Clearing heat and treating rheumatism & Guangxi & $\begin{array}{l}\text { MUCH- } \\
\text { ZLs-045 }\end{array}$ \\
\hline
\end{tabular}


Table 1 Plant leaves used to wrap zongzi in China based on our field work (Continued)

\begin{tabular}{|c|c|c|c|c|c|c|c|}
\hline No. & Scientific name & Family name & $\begin{array}{l}\text { Chinese } \\
\text { name }\end{array}$ & $\begin{array}{l}\text { Life } \\
\text { form }\end{array}$ & Medicinal value & Main distribution & $\begin{array}{l}\text { Voucher } \\
\text { number }\end{array}$ \\
\hline 26 & Musa acuminata Colla & Musaceae & $\begin{array}{l}\text { 小果野 } \\
\text { 蕉 }\end{array}$ & Herb & Clearing heat & $\begin{array}{l}\text { Yunnan and } \\
\text { Guangxi }\end{array}$ & $\begin{array}{l}\text { MUCH- } \\
\text { ZLs-015 }\end{array}$ \\
\hline 27 & Musa balbisiana Colla & Musaceae & 野蕉 & Herb & - - & $\begin{array}{l}\text { Yunnan and } \\
\text { Guangxi }\end{array}$ & $\begin{array}{l}\text { MUCH- } \\
\text { ZLs-055 }\end{array}$ \\
\hline 28 & $\begin{array}{l}\text { Musa basjoo Siebold and } \\
\text { Zucc. ex linuma }\end{array}$ & Musaceae & 芭蕉 & Herb & Clearing heat and diuresis & Southern China & $\begin{array}{l}\text { MUCH- } \\
\text { ZLs-001 }\end{array}$ \\
\hline 29 & Musa nana Lour. & Musaceae & 香蕉 & Herb & Clearing heat, detoxification, and diuresis & $\begin{array}{l}\text { Yunnan, } \\
\text { Guangdong, } \\
\text { Guangxi and } \\
\text { Fujian }\end{array}$ & $\begin{array}{l}\text { MUCH- } \\
\text { ZLs-003 }\end{array}$ \\
\hline 30 & Musa sapientum L. & Musaceae & 大蕉 & Herb & Clearing heat and diminishing inflammation & $\begin{array}{l}\text { Yunnan, } \\
\text { Guangdong, and } \\
\text { Guangxi }\end{array}$ & $\begin{array}{l}\text { MUCH- } \\
\text { ZLs-016 }\end{array}$ \\
\hline 31 & Musa itineras Tutcher & Musaceae & 野芭蕉 & Herb & Clearing heat and antimalarial effect & $\begin{array}{l}\text { Yunnan, Guizhou, } \\
\text { and Guangxi }\end{array}$ & $\begin{array}{l}\text { MUCH- } \\
\text { ZLs-002 }\end{array}$ \\
\hline 32 & Nelumbo nucifera Gaertn. & Nymphaeaceae & 莲 & Herb & Clearing heat, detoxification, and hemostasis & $\begin{array}{l}\text { Jiangsu, Zhejiang, } \\
\text { Guangdong, and } \\
\text { Hainan }\end{array}$ & $\begin{array}{l}\text { MUCH- } \\
\text { ZLs-021 }\end{array}$ \\
\hline 33 & $\begin{array}{l}\text { Pandanus austrosinensis T. } \\
\text { L.Wu }\end{array}$ & Pandanaceae & 露兒草 & Herb & $\begin{array}{l}\text { Clearing heat, detoxification, and diminishing } \\
\text { inflammation }\end{array}$ & $\begin{array}{l}\text { Guangdong and } \\
\text { Hainan }\end{array}$ & $\begin{array}{l}\mathrm{MUCH}- \\
\mathrm{ZLs}-022\end{array}$ \\
\hline 34 & $\begin{array}{l}\text { Pandanus tectorius } \\
\text { Parkinson ex Du Roi }\end{array}$ & Pandanaceae & 露兒树 & Tree & Clearing heat and diuresis & $\begin{array}{l}\text { Guangdong and } \\
\text { Hainan }\end{array}$ & $\begin{array}{l}\text { MUCH- } \\
\text { ZLs-023 }\end{array}$ \\
\hline 35 & $\begin{array}{l}\text { Perilla frutescens (L.) } \\
\text { Britton }\end{array}$ & Labiatae & 紫苏 & Herb & $\begin{array}{l}\text { Treating common cold, alleviating emesis, } \\
\text { invigorating spleen and stomach }\end{array}$ & Liaoning & $\begin{array}{l}\text { MUCH- } \\
\text { ZLs-052 }\end{array}$ \\
\hline 36 & $\begin{array}{l}\text { Phragmites australis (Cav.) } \\
\text { Trin. ex Steud. }\end{array}$ & Gramineae & 芦苇 & Herb & Clearing heat and detoxification & Northern China & $\begin{array}{l}\text { MUCH- } \\
\text { ZLs-029 }\end{array}$ \\
\hline 37 & Phrynium capitatum Willd. & Marantaceae & 柊叶 & Herb & $\begin{array}{l}\text { Clearing heat, detoxification, hemostasis, } \\
\text { relieving sore throat, diminishing inflammation } \\
\text { and anti-alcoholism }\end{array}$ & $\begin{array}{l}\text { Guangdong, } \\
\text { Guangxi, Hainan } \\
\text { and Yunnan }\end{array}$ & $\begin{array}{l}\text { MUCH- } \\
\text { ZLs-004 }\end{array}$ \\
\hline 38 & $\begin{array}{l}\text { Phrynium hainanense T. L. } \\
\text { Wu and S. J. Chen }\end{array}$ & Marantaceae & $\begin{array}{l}\text { 海南柊 } \\
\text { 叶 }\end{array}$ & Herb & Clearing heat & Hainan & $\begin{array}{l}\text { MUCH- } \\
\text { ZLs-047 }\end{array}$ \\
\hline 39 & $\begin{array}{l}\text { Phrynium placentarium } \\
\text { (Lour.) Merr. }\end{array}$ & Marantaceae & $\begin{array}{l}\text { 尖苞柊 } \\
\text { 叶 }\end{array}$ & Herb & $\begin{array}{l}\text { Clearing heat, detoxification, hemostasis, and } \\
\text { diuresis }\end{array}$ & $\begin{array}{l}\text { Guangdong, } \\
\text { Guangxi, and } \\
\text { Yunnan }\end{array}$ & $\begin{array}{l}\text { MUCH- } \\
\text { ZLs-017 }\end{array}$ \\
\hline 40 & $\begin{array}{l}\text { Phyllostachys bambusoides } \\
\text { Siebold and Zucc. }\end{array}$ & Gramineae & 桂竹 & Bamboo & Clearing heat and detoxification & Southern China & $\begin{array}{l}\text { MUCH- } \\
\text { ZLs-018 }\end{array}$ \\
\hline 41 & $\begin{array}{l}\text { Phyllostachys heteroclada } \\
\text { Oliv. }\end{array}$ & Gramineae & 水竹 & Bamboo & Clearing heat and detoxification & $\begin{array}{l}\text { Yunnan and } \\
\text { Guangxi }\end{array}$ & $\begin{array}{l}\mathrm{MUCH}- \\
\mathrm{ZLs}-024\end{array}$ \\
\hline 42 & $\begin{array}{l}\text { Phyllostachys heterocycla } \\
\text { (Carrière) Matsum. }\end{array}$ & Gramineae & 毛竹 & Bamboo & $\begin{array}{l}\text { Clearing heat, detoxification, diminishing } \\
\text { inflammation, alleviating emesis, and relieving } \\
\text { cough }\end{array}$ & $\begin{array}{l}\text { Sichuan, Zhejiang, } \\
\text { and Henan }\end{array}$ & $\begin{array}{l}\text { MUCH- } \\
\text { ZLs-026 }\end{array}$ \\
\hline 43 & Piper sarmentosum Roxb. & Piperaceae & 假蒟 & Herb & $\begin{array}{l}\text { Diminishing inflammation, treating } \\
\text { rheumatism, analgesia, and antimalarial effect }\end{array}$ & $\begin{array}{l}\text { Guangdong and } \\
\text { Guangxi }\end{array}$ & $\begin{array}{l}\mathrm{MUCH}- \\
\mathrm{ZLs}-025\end{array}$ \\
\hline 44 & $\begin{array}{l}\text { Pleioblastus amarus (Keng) } \\
\text { Keng f. }\end{array}$ & Gramineae & 苦竹 & Bamboo & $\begin{array}{l}\text { Clearing heat, detoxification, and removing the } \\
\text { phlegm }\end{array}$ & $\begin{array}{l}\text { Yunnan and } \\
\text { Guizhou }\end{array}$ & $\begin{array}{l}\text { MUCH- } \\
\text { ZLs-042 }\end{array}$ \\
\hline 45 & $\begin{array}{l}\text { Podocarpus nagi (Thunb.) } \\
\text { Pilg. }\end{array}$ & Podocarpaceae & 竹柏 & Tree & Hemostasis and treating common cold & $\begin{array}{l}\text { Guangdong and } \\
\text { Guangxi }\end{array}$ & $\begin{array}{l}\text { MUCH- } \\
\text { ZLs-035 }\end{array}$ \\
\hline 46 & Quercus dentata Thunb. & Fagaceae & 葪树 & Tree & $\begin{array}{l}\text { Clearing heat, hemostasis, diuresis, and treating } \\
\text { hemorrhoid }\end{array}$ & $\begin{array}{l}\text { Shanxi, Henan, } \\
\text { and Shandong }\end{array}$ & $\begin{array}{l}\text { MUCH- } \\
\text { ZLs-053 }\end{array}$ \\
\hline 47 & $\begin{array}{l}\text { Rhapis excelsa (Thunb.) } \\
\text { Henry }\end{array}$ & Palmae & 棕竹 & Shrub & $\begin{array}{l}\text { Treating rheumatism, hemostasis, and } \\
\text { alleviating emesis }\end{array}$ & $\begin{array}{l}\text { Guangxi and } \\
\text { Yunnan }\end{array}$ & $\begin{array}{l}\text { MUCH- } \\
\text { ZLs-019 }\end{array}$ \\
\hline 48 & Saccharum officinarum L. & Gramineae & 甘蔗 & Herb & $\begin{array}{l}\text { Clearing heat, detoxification, and } \\
\text { hypoglycemic effect }\end{array}$ & $\begin{array}{l}\text { Fujian and } \\
\text { Guangdong }\end{array}$ & $\begin{array}{l}\text { MUCH- } \\
\text { ZLs-040 }\end{array}$ \\
\hline 49 & Sorghum bicolor (L.) & Gramineae & 高粱 & Herb & Diminishing inflammation and treating & Hunan, Hubei, & $\mathrm{MUCH}-$ \\
\hline
\end{tabular}


Table 1 Plant leaves used to wrap zongzi in China based on our field work (Continued)

\begin{tabular}{|c|c|c|c|c|c|c|c|}
\hline No. & Scientific name & Family name & $\begin{array}{l}\text { Chinese } \\
\text { name }\end{array}$ & $\begin{array}{l}\text { Life } \\
\text { form }\end{array}$ & Medicinal value & Main distribution & $\begin{array}{l}\text { Voucher } \\
\text { number }\end{array}$ \\
\hline & Moench & & & & rheumatism & and Shandong & ZLs-030 \\
\hline 50 & Sterculia nobilis Sm. & Sterculiaceae & 苹婆 & Tree & Treating rheumatism & $\begin{array}{l}\text { Guangdong and } \\
\text { Guangxi }\end{array}$ & $\begin{array}{l}\text { MUCH- } \\
\text { ZLs-027 }\end{array}$ \\
\hline 51 & Terminalia catappa $\mathrm{L}$. & Myrtiflorae & 榄仁树 & Tree & $\begin{array}{l}\text { Treating rheumatism, detoxification, relieving } \\
\text { cough and hypoglycemic effect }\end{array}$ & Taiwan & $\begin{array}{l}\mathrm{MUCH}- \\
\text { ZLs-048 }\end{array}$ \\
\hline 52 & $\begin{array}{l}\text { Thysanolaena maxima } \\
\text { (Roxb.) Kuntze }\end{array}$ & Gramineae & 粽叶芦 & Herb & $\begin{array}{l}\text { Detoxification, treating bronchitis, hepatitis, } \\
\text { and diarrhea }\end{array}$ & $\begin{array}{l}\text { Guangdong, } \\
\text { Guangxi, } \\
\text { Guizhou, and } \\
\text { Yunnan }\end{array}$ & $\begin{array}{l}\text { MUCH- } \\
\text { ZLs-005 }\end{array}$ \\
\hline 53 & Tilia tuan Szyszył. & Tiliaceae & 椴树 & Tree & Treating rheumatism and ostalgia & Beijing & $\begin{array}{l}\mathrm{MUCH}- \\
\text { ZLs-050 }\end{array}$ \\
\hline 54 & $\begin{array}{l}\text { Trachycarpus fortunei } \\
\text { (Hook.) H. Wendl. }\end{array}$ & Palmae & 棕㭣 & Tree & Hemostasis and diuresis & $\begin{array}{l}\text { Hunan, Jiangxi, } \\
\text { and Sichuan }\end{array}$ & $\begin{array}{l}\text { MUCH- } \\
\text { ZLs-036 }\end{array}$ \\
\hline 55 & $\begin{array}{l}\text { Vernicia fordii (Hemsl.) Airy } \\
\text { Shaw }\end{array}$ & Euphorbiaceae & 油桐 & Tree & $\begin{array}{l}\text { Removing the phlegm and promoting } \\
\text { digestion and assimilation }\end{array}$ & $\begin{array}{l}\text { Hunan and } \\
\text { Sichuan }\end{array}$ & $\begin{array}{l}\text { MUCH- } \\
\text { ZLs-038 }\end{array}$ \\
\hline 56 & Zea mays $\mathrm{L}$. & Gramineae & 玉米 & Herb & Clearing heat, hypoglycemic effect & $\begin{array}{l}\text { Shandong and } \\
\text { Northwestern } \\
\text { China }\end{array}$ & $\begin{array}{l}\text { MUCH- } \\
\text { ZLs-051 }\end{array}$ \\
\hline 57 & $\begin{array}{l}\text { Zizania latifolia (Griseb.) } \\
\text { Turcz. ex Stapf }\end{array}$ & Gramineae & 菰 & Herb & - - & Jiangsu & $\begin{array}{l}\mathrm{MUCH}- \\
\text { ZLs-054 }\end{array}$ \\
\hline
\end{tabular}

plant families, the most dominant family was Gramineae with 20 species (35.1\%), followed by Musaceae (10.5\%) Zingiberaceae (8.8\%), Liliaceae (7.0\%), and Palmae (7.0\%), with 6, 5, 4, and 4 species, respectively. As for the plant genera, Musa, Aspidistra, and Indocalamus were the three most common genera, with 6,4 , and 4 species, respectively, followed by Alpinia, Phrynium, Phyllostachys, Dendrocalamus, and Pandanus. By contrast, other genera contained one species only (Tables 1 and 2). Within these 57 plant species, 30 plant species were herbaceous $(52.6 \%)$, while 13 were trees or bamboos (22.8\%) (Fig. 4). However, only one species, Rhapis excelsa, was liana and no shrubs were discovered. When compared with previous investigations $[4,5,13]$, the species of plant leaves were quite different from our findings. In Veracruz of Mexica, Marantaceae, Heliconiaceae, and Araliaceae were the three most dominant families whose leaves were used to wrap tamales, and only one common species was found, namely, Zea mays whose leaves could be used as ZLs by Chinese people [4]. The species of plant leaves as food wrappers for sarma in Turkey and the Balkans are all different from ZLs we investigated mostly because the sarma leaves could be eaten while the ZLs were only used for wrapping purposes $[5,13]$. Our surveys together with the previous studies highlight the significance of ethnobotanical investigations regarding the plant leaves for food wrapping. Extensive investigations are still worthwhile to be conducted in some places, especially in Latin America and Southeast Asia where people consume zongzi-like food [6].
The species of ZLs employed in each province of China are listed in Table 3. Some similarities and differences between the species of ZLs in different regions have been observed, which partly reflected the cultural diversity of zongzi. The species of ZLs used by the people in the south of China were much more numerous than that in the north of China (Table 3), which may due to the differences between plant resources, people's experience and observation towards ZLs and traditional culture. The number of ZLs used in Guangxi Province was the maximum with 28 species, followed by Yunnan, Guangdong, Hainan, and Guizhou provinces with 24, 21, 15 , and 15 species, respectively. However, the traditional ZLs had not been found in Biru and Leiwuqi counties, and Chengguan District in Tibet because the local people did not have the traditional custom of eating zongzi, or they bought the commercialized ZLs such as the leaves of Indocalamus herklotsii from adjacent Sichuan Province due to the local limitations of plant resources. Among these ZLs, the leaves of Indocalamus spp. were the most common ZLs in Southern China; however, the leaves of Phragmites australis were found to be the most dominant in Northern China. Additionally, the husk leaves or leaves of $Z$. mays were regarded as traditional ZLs in 13 provinces located in both the south and north of China, which may partly be because of the widespread cultivation and people's similar traditional knowledge related to $Z$. mays.

According to our surveys, some similarities and differences of ZLs among or within ethnic groups were discovered. The ZLs of Phrynium capitatum were widely 


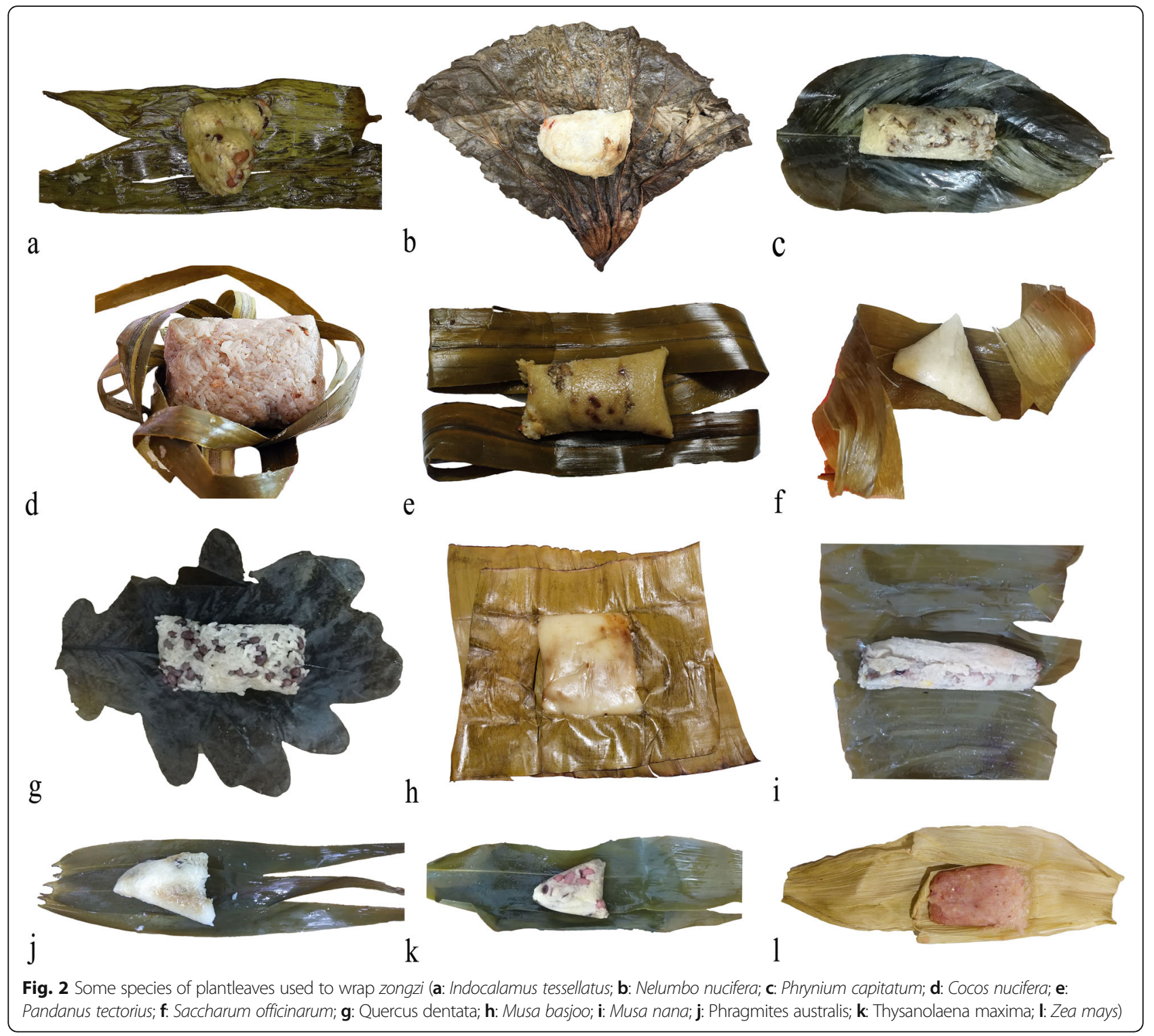

used by the Han people in the west and south of Guangdong Province. However, it was hardly found among the Han people in the east, mainly due to the distribution area of $P$. capitatum. It was commonly believed by the Han people in Shanghai that the usage of the traditional ZLs of Indocalamus spp. was originated from the Han communities in Anhui Province because of the cultural communication in the course of economic exchange. Even though Piper sarmentosum is widely distributed in Guangxi Province, it was told that $P$. sarmentosum leaves were mainly used by the Zhuang people in East Guangxi. It was rarely used by the same ethnic group in other parts of Guangxi because, for the Zhuang people in the east part, the knowledge that $P$. sarmentosum leaves could be used as ZLs was inherited from their ancestors for a long time. Therefore, the similarities and differences of the species of ZLs among and within ethnic groups could be considered the results of plant distribution, the heritage of traditional knowledge, and cultural exchange.

The leaves of Zizania latifolia represent the earliest ZLs, which have been used since the Spring and Autumn period of China (770-476 BC) [22]. Even though using the ZLs of Z. latifolia was prevalent in ancient times, it has now greatly lost its popularity based on our field investigations. According to the areas we investigated, only people in Suzhou City of Jiangsu Province in China still used this species as one of the traditional ZLs. The leaf of Melia azedarach was another ancient ZL, which was recorded in the Chinese ancient book, Xu Qi Xie Zhi, written by $\mathrm{Wu}$ Jing of Southern Dynasties of China (420-589 AD) [23]. However, it had not been discovered 


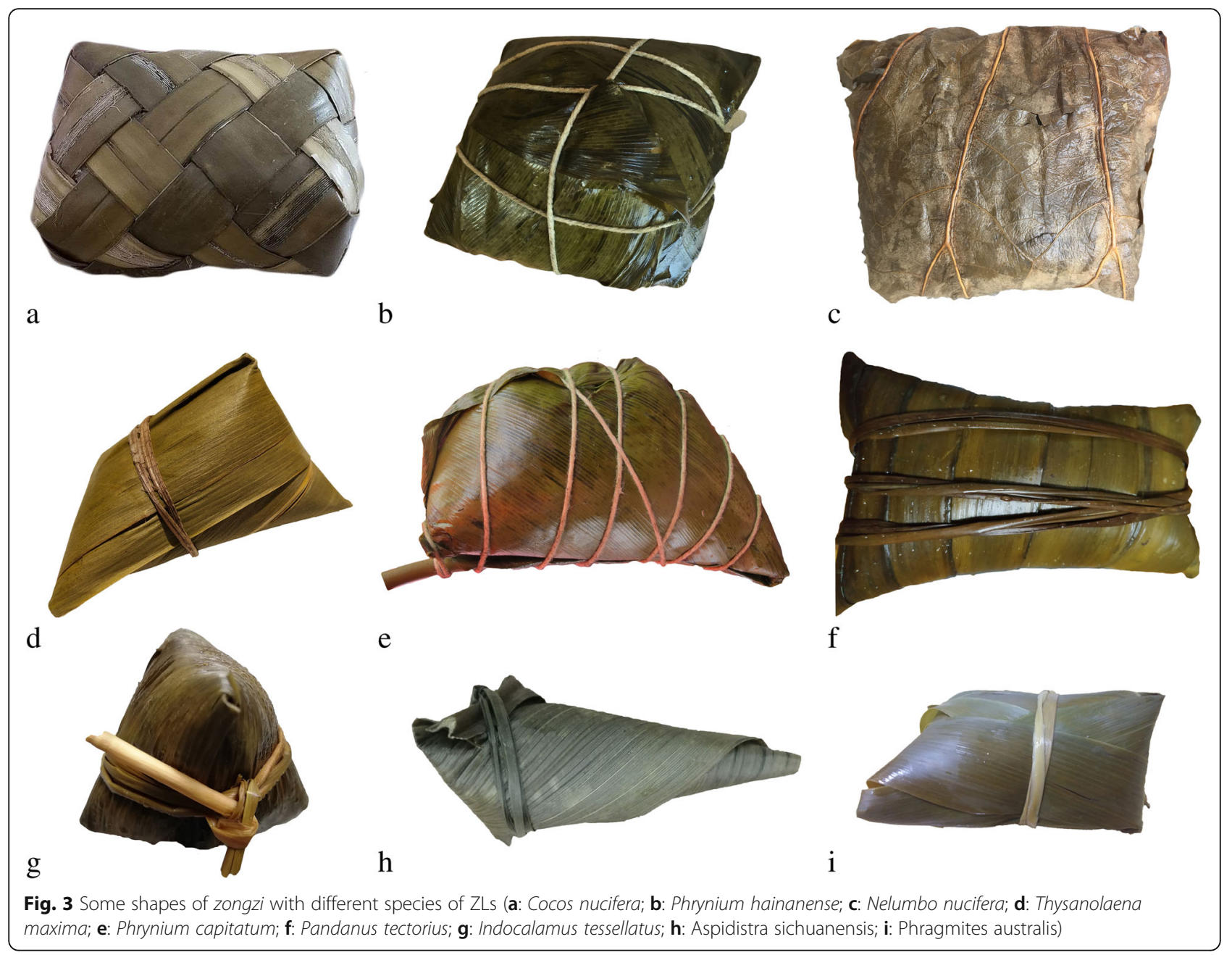

Table 2 Taxonomic diversity of plant species in China

\begin{tabular}{lllll}
\hline Family & Number of genera & Percentage & Number of species & Percentage \\
\hline Gramineae & 14 & 36.8 & 20 & 35.1 \\
Palmae & 4 & 10.5 & 4 & 7.0 \\
Zingiberaceae & 3 & 7.9 & 5 & 8.8 \\
Labiatae & 2 & 5.3 & 2 & 3.5 \\
Tiliaceae & 2 & 5.3 & 2 & 3.5 \\
Liliaceae & 1 & 2.6 & 4 & 7.0 \\
Marantaceae & 1 & 2.6 & 3 & 5.3 \\
Musaceae & 1 & 2.6 & 6 & 10.5 \\
Pandanaceae & 1 & 2.6 & 2 & 3.5 \\
Other families & 9 & 23.7 & 9 & 15.8 \\
Total & 38 & 100 & 57 & 100 \\
\hline
\end{tabular}




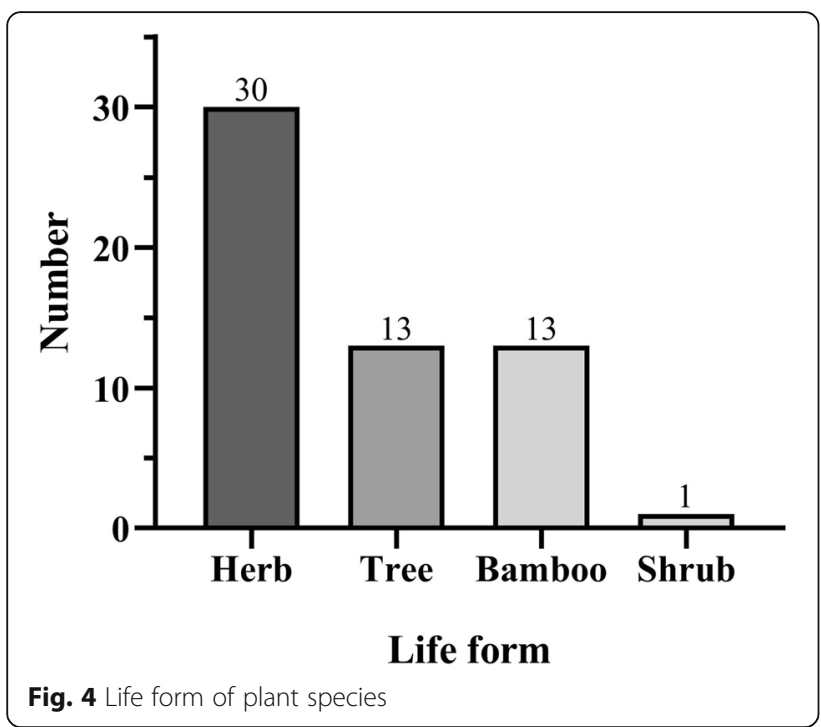

as being used by people to wrap zongzi. Studying the inheritance and change of traditional ZLs in each area could prove significant to the conservation of biodiversity of ZLs.

In addition to plant leaves, the shells of bamboo shoots, according to our interviews, can also be traditionally used to wrap zongzi in some regions such as $\mathrm{Si}$ chuan, Hunan, and Zhejiang provinces. Some species of plant leaves with correct length and good flexibility are good resources to bind zongzi apart from their wrapping abilities, such as the leaves of Phragmites australis, Cocos nucifera, and Livistona chinensis. Traditionally, the leaves or stems of Imperata cylindrica, Iris tectorum, Oryza sativa, Trachycarpus fortune, Typha angustifolia, and Cyperus malaccensis can be used as binding materials as well. However, it has become more and more common to use strings made of cotton or flax to bind zongzi at present because of their convenience and low prices.

\section{The folk legends of ZLs}

According to our surveys, some folk legends of ZLs had been widely spread. It is generally believed that both the Dragon Boat Festival and the traditional custom of eating zongzi are to commemorate the great Chinese patriotic poet, Qu Yuan (339-278 BC), who drowned himself to death for his country in the Miluo River (Yueyang City, Hunan Province, at present). At that time, when people heard the news of his suicide, they fell into a deep sadness. Then, it was agreed that scattering the cooked glutinous rice into the river as a sacrifice for $\mathrm{Qu}$ Yuan was beneficial to express these feelings. However, the food thrown into the river was mainly robbed and eaten by Jiaolong, the mythical dragon-like creature at the time. Fortunately, Jiaolong could be effectively deterred by the plant leaves of Melia azedarach. Using this knowledge, the people started using plant leaves to wrap glutinous rice before it was thrown into the river so as to protect the food for $\mathrm{Qu}$ Yuan from being eaten by Jiaolong. This folk legend was widely spread and passed down from generation to generation throughout China. Over time, different ZLs from various plant species are gradually adopted on the Dragon Boat Festival in China. Our investigations were consistent with those recorded in the ancient books, Xu Qi Xie Zhi and Jing Chu Sui Shi Ji [23], which, to some extent, indicated the stability of cultural inheritance of ZLs in China.

Interestingly, a particular folk legend concerning the leaves of Miscanthus floridulus was well known by the She people in Chibi Village of Fujian Province in Southern China. This legend is related to the revenge and atrocity of Zhu Yuanzhang (1328-1398 AD), who was the first emperor of the Ming Dynasty (1368-1644 AD) [24]. When Zhu Yuanzhang was a cowboy in his childhood, he did not take care of his cow. As a result, his cow usually audaciously trampled and ate the vegetables cultivated by the She people. One time, when an old She woman found that the cow was eating her vegetables, she was so angry that she expelled it with a whip. After knowing that his cow was seriously lashed, Zhu Yuanzhang became furious and made a promise to revenge one day. When he became the emperor of the Ming Dynasty, he still remembered the humiliation that he experienced in his childhood and he commanded his army to kill the She people. Therefore, the She people had to leave their hometowns, those of whom in Guangdong Province escaped to the remote mountains distributed in the east of Fujian Province. They were so afraid of being killed that they could not collect the bamboo leaves that grew down the hill at lower altitudes, which they originally used to wrap zongzi during the Dragon Boat Festival. One patriarch came up with a good idea that the leaves of $M$. floridulus could also be used as ZLs. This novel way to wrap zongzi was widely spread and accepted by the She people. From then on, the tradition of using the ZLs of M. floridulus had been gradually formed. While the origin and authenticity of this legend remain to be determined and validated, it is possible that these legends about ZLs could be partly responsible for the diversity of the traditional culture of the Dragon Boat Festival.

\section{Collection and processing of ZLS}

According to our interviews, despite a diversity of plant leaves used, the people across different regions had almost the same processes to collect and process ZLs. In general, the fresh healthy ZLs are collected during the Dragon Boat Festival in the mountains or home gardens and then washed with fresh water to remove dirt and dust. After the leaves are cleaned up, they are immersed in boiling water until they become soft and flexible enough to wrap the prepared glutinous rice. The 
Table 3 The species of ZLs used in each province of China

\begin{tabular}{|c|c|c|c|c|}
\hline Province & $\begin{array}{l}\text { Investigated area (county or county-level } \\
\text { zone) }\end{array}$ & Linguistic group & Species of ZLs (No.) & Number \\
\hline East China & & & & 16 \\
\hline Shandong & $\begin{array}{l}\text { Zhuchengshi, Dongchangfu, Pingyi, } \\
\text { Decheng }\end{array}$ & Han & $36,46,49,56$ & 4 \\
\hline Jiangsu & Gaoyou, Peixian, Sihong, Wuzhong & Han & $32,36,57$ & 3 \\
\hline Anhui & Tongqiao, Lujiang, Huaining, Lixin & Han & 20,36 & 2 \\
\hline Zhejiang & Taishun, Ruian, Jingning, Putuo, Xihu & Han, She & $21,24,32,36,42$ & 5 \\
\hline Fujian & Xiapu, Hanjiang, Shanghang, Cangshan & Han, She & $3,13,14,20,21,24,28,40,48$ & 9 \\
\hline Shanghai & Hongkou, Pudong, Fengxian & Han & $20,21,32$ & 3 \\
\hline South China & & & & 36 \\
\hline Guangdong & $\begin{array}{l}\text { Sanxiang, Qingcheng, Haifeng, Huidong, } \\
\text { Deqing, Leizhou, Haizhu }\end{array}$ & Han, Yao & $\begin{array}{l}4,13,16,18,19,20,21,28,29,30,32,33,34,37 \\
39,40,43,45,48,50,52\end{array}$ & 21 \\
\hline Guangxi & $\begin{array}{l}\text { Yongfu, Jingxi, Leye, Huanjing, Lingshan, } \\
\text { Pingxiang, Pingle }\end{array}$ & Han, Zhuang, Yao & $\begin{array}{l}4,5,9,11,13,14,18,19,20,21,23,25,26,27,28 \\
29,30,31,34,37,39,40,41,43,45,47,50,52\end{array}$ & 28 \\
\hline Hainan & $\begin{array}{l}\text { Ledong, Wenchang, Meilan, Lingshui, } \\
\text { Wanning }\end{array}$ & Han, Li, Miao & $\begin{array}{l}1,10,14,20,21,22,27,28,29,32,33,34,37,38 \\
40\end{array}$ & 15 \\
\hline Central China & & & & 17 \\
\hline Hubei & Xiangyang, Hongan, Hongshan, Xiaoting & Han & $28,36,49,54,56$ & 5 \\
\hline Hunan & $\begin{array}{l}\text { Guiyang, Lixian, Qidong, Xinshao, Jianghua, } \\
\text { Tongdao }\end{array}$ & Han, Dong, Yao & $6,13,16,19,20,21,28,29,37,40,49,54,55$ & 13 \\
\hline Henan & Lushi, Xiping, Taikang, Minquan & Han & $20,21,36,42,46,56$ & 6 \\
\hline Jiangxi & Huichang, Ningdu, Shangli, Dean & Han & $13,20,21,28,36,54$ & 6 \\
\hline North China & & & & 6 \\
\hline Beijing & Yanqing, Haidian, Shunyi & Han, Man & 36,53 & 2 \\
\hline Tianjin & Baodi, Hedong, Hexi & Han & 36 & 1 \\
\hline Hebei & Cixian, Xianghe, Lixian, Suning & Han & 36 & 1 \\
\hline Shanxi & Liaocheng, Ruicheng, Xiaoyi, Yanggao & Han & 36,46 & 2 \\
\hline $\begin{array}{l}\text { Inner } \\
\text { Mongolia }\end{array}$ & $\begin{array}{l}\text { Keerqin, Alashanzuoqi, Zhalantun, } \\
\text { Etuokeqianqi }\end{array}$ & Han, Mongolian & 36,56 & 2 \\
\hline $\begin{array}{l}\text { Northwest } \\
\text { China }\end{array}$ & & & & 6 \\
\hline Ningxia & Jingyuan, Dawukou, Xingqing, Shapotou & Han, Hui & 36 & 1 \\
\hline Xinjiang & $\begin{array}{l}\text { Akesu, Tianshan, Cabuchaerxibo, Kuche, } \\
\text { Bohu }\end{array}$ & Han, Uighur & 36,56 & 2 \\
\hline Qinhai & Chengxi, Huangzhong, Geermu & Han, Tibetan & 36,56 & 2 \\
\hline Shanxi & Luonan, Baqiao, Baishui, Shenmu & Han & $32,36,46,56$ & 4 \\
\hline Gansu & Anning, Zhenyuan, Huining & Han & $28,32,36,56$ & 4 \\
\hline $\begin{array}{l}\text { Southwest } \\
\text { China }\end{array}$ & & & & 30 \\
\hline Sichuan & $\begin{array}{l}\text { Nanxi, Pengxi, Hanyuan, Fucheng, Mianning, } \\
\text { Chongzhou }\end{array}$ & Han, Yi, Qiang & $6,8,13,20,21,28,36,40,42,54,55,56$ & 12 \\
\hline Yunnan & $\begin{array}{l}\text { Panlong, Ludian, Eshan, Mengla, Maguan, } \\
\text { Shuangjiang, Jinping, Xiangyun, Yongsheng }\end{array}$ & $\begin{array}{l}\text { Han, Dai, Hani, Jinuo, Yi, } \\
\text { Yao, Lisu, Tujia, Maonan }\end{array}$ & $\begin{array}{l}4,5,6,7,8,9,12,13,15,20,21,22,26,27,28,29 \\
30,37,39,40,41,44,47,52,56\end{array}$ & 24 \\
\hline Guizhou & $\begin{array}{l}\text { Yuqing, Suiyang, Tongzi, Xingren, Sandu, } \\
\text { Taijiang }\end{array}$ & $\begin{array}{l}\text { Han, Miao, Dong, Buyi, } \\
\text { Shui }\end{array}$ & $5,6,7,8,9,13,18,20,21,28,31,32,40,44,52$ & 15 \\
\hline Tibet & Chengguan, Leiwuqi, Biru & Tibetan & - - & 0 \\
\hline Chongqing & Nanchuan, Jiulongpo, Kaizhou & Han & $20,21,28,56$ & 4 \\
\hline $\begin{array}{l}\text { Northeast } \\
\text { China }\end{array}$ & & & & 3 \\
\hline
\end{tabular}


Table 3 The species of ZLs used in each province of China (Continued)

\begin{tabular}{|c|c|c|c|c|}
\hline Province & $\begin{array}{l}\text { Investigated area (county or county-level } \\
\text { zone) }\end{array}$ & Linguistic group & Species of ZLs (No.) & Number \\
\hline Jilin & Fengman, Nanguan, Yanji, Qianan & Han, Korean & 36,56 & 2 \\
\hline Heilongjiang & Yian, Daowai, Duerbote & Han, Man, Korean & 36,56 & 2 \\
\hline Liaoning & Shuangta, Yinchuan, Qingyuan, Fuxin & Han, Korean, Mongolian & 35,36 & 2 \\
\hline Other areas & & & & 6 \\
\hline Taiwan & Xinzhu, Annan, Wenshan, Banqiao & Han, Gaoshan & $2,3,17,21,51$ & 5 \\
\hline Xianggang & Quanwan, Shatian & Han & $20,21,28$ & 3 \\
\hline Macao & Dangzai, Datang & Han & 20,21 & 2 \\
\hline
\end{tabular}

The numbers of species of ZLs are equivalent to the numbers in Table 1

necessity of preliminary heat treatment was also reported by Dogan and colleagues [5] when the leaves were used to wrap sarma in Turkey or the Balkans. The leaves used for sarma are eaten afterward, but ZLs are just for the package. Once packed with ZLs and bound tightly, zongzi as a whole is then boiled or steamed until they were suitable to eat. The similarity in the collection and processing of ZLs exemplifies the unity of culture surrounding the zongzi or the Dragon Boat Festival in China.

\section{Contribution to zongzi flavor}

The zongzi flavor can be affected by both the inside fillings and the ZLs [9]. It was reported that some species of plant leaves such as Oreopanax flaccidus leaves could add a unique flavor to tamales [4]. According to our surveys, in general, over $80 \%$ of people preferred to use the ZLs which they believed were more fragrant. It was commonly believed that ZLs could vastly contribute to the zongzi flavor. For example, people in some regions of Southern China have found that zongzi wrapped by the leaves of Nelumbo nucifera, Piper sarmentosum, Indocalamus spp., and Musa spp. have a special fragrance, and it was believed by the Li ethnic group in Hainan Province that zongzi with Cocos nucifera leaves had coconutlike flavor that came from the leaves. The areas where people are familiar with the flavor contributions of ZLs were provided in Additional file 1: Table S1.

The flavor compounds from Alpinia zerumbet [25], Hedychium coronarium [26], Indocalamus latifolius [27], I. tessellatus [28], Musa acuminate [29], Nelumbo nucifera [30], Perilla frutescens [31], Quercus dentata [32], and Terminalia catappa [33] have been previously characterized and identified. For instance, nine critical flavor components have been identified by GC-MS from the leaves of $I$. tessellatus including $p$-vinylphenol, $p$-vinylguaiacol, diphenylmethanone, 2, 2' -diethylbiphenyl, 2, 6diisopropylnaphthalene, (Z)-phytol, eicosanenitrile, 2phenyltridecane, and (E)-phytol [28]. These results therefore supported the traditional knowledge that these species of ZLs could contribute the zongzi flavor.
However, as far as we know, there have been no reports on the flavor compounds of other ZLs yet. Consequently, further studies are greatly needed to fully characterize the aroma-active constituents, which will encourage them to be developed as naturally refreshing agents for our environmental sanitary or natural flavor substances with health-promoting properties for food.

\section{Antiseptic functions of ZLs}

According to our interviews, apart from the contribution to the zongzi flavor, some species of ZLs are believed to have antiseptic properties, which results in relatively long-term storage time of zongzi under natural conditions. The Dragon Boat Festival is celebrated at the end of the spring and the beginning of the summer when the food is easily attacked by spoilage organisms because of the suitable temperature and humidity [34]. Thus, ZLs with antiseptic functions are more favorable. According to our surveys in the local areas, 26 species of ZLs were considered to be responsible for the shelf life of zongzi, including the leaves of Aspidistra spp., Cocos nucifera, Evodia glabrifolia, Fargesia fractiflexa, Indocalamus spp., Magnolia officinalis, Miscanthus floridulus, Monocladus amplexicaulis, Musa spp., Pandanus tectorius, Phragmites australis, Phrynium capitatum, Piper sarmentosum, Quercus dentata, and Thysanolaena maxima. For instance, according to the interviews, the sweet zongzi with ZLs of I. latifolius, P. australis, or Q. dentata would not be spoiled during 10 days of storage in summer, and the salty-meat zongzi with ZLs of P. tectorius, M. basjoo, or $C$. nucifera could still stay fresh within five days under natural ventilation condition. The areas where people are familiar with the antiseptic functions of ZLs were listed in Additional file 1: Table S1.

At present, antimicrobial properties of packaging materials have attracted public concerns and have been included in the next generation of food packaging [35]. Based on previous studies, the polar extracts or the essential oils from the leaves of $A$. elatior [36], C. nucifera [37], I. latifolius [38], I. tessellatus [39], M. officinalis 
[40], M. acuminata [41], M. sapientum [42], P. tectorius [43], P. australis [44], P. capitatum [19], P. sarmentosum [45, 46], Q. dentata [47], and T. maxima [19] showed good antimicrobial activities. For instance, the essential oils of the leaves of P. capitatum and T. maxima presented considerable activity against spoilage organisms such as Aspergillus fumigatus and Candida albicans, with MIC (minimum inhibitory concentration) ranging from 64 to $1024 \mathrm{mg} / \mathrm{mL}$ [19], and the acetone extracts from the leaves of $M$. acuminata showed significant antifungal activities against Aspergillus terreus and Penicillium solitum after 5 days, with the inhibition rate of mycelial growth of 81.1 and $45.6 \%$, respectively [41]. These results are in accordance with the traditional knowledge that these traditional ZLs have antiseptic functions, suggesting the potential utility of associated traditional botanical knowledge surrounding ZLs.

Previous research showed that the fruits extracts containing flavonoids from $M$. balbisiana exhibited antibacterial activity against Shigella dysenteriae ATCC 13313, with MIC value ranging from 5 to $10 \% \mathrm{w} / \mathrm{v}$ [48], and the extracts from rhizomes and flowers of $M$. basjoo showed antimicrobial activity against Staphylococcus aureus and methicillin-resistant Staphylococcus aureus [49]. However, to the best of our knowledge, the anti-microbial activities of the leaves of both M. balbisiana and M. basjoo have not been reported yet. Furthermore, no studies have been yet reported regarding the antimicrobial properties of ZLs of A. oblanceifolia, A. sichuanensis, A. zongbayi, E. glabrifolia, F. fractiflexa, I. guangdongensis, I. herklotsii, M. amplexicaulis, M. floridulus, M. nana, Musa itineras, $P$. hainanense, and P. placentarium, even though people believe that they can increase the storage time of zongzi.. Therefore, further studies on the antimicrobial bioactivity of ZLs are worthwhile to be conducted. The ZLs with antiseptic functions are expected to be further developed as biodegradable packaging materials for food, and the bioactive compounds have great potential to be applied in food preservation and drug development.

\section{Medicinal value of ZLs}

According to our survey, among the 57 species of ZLs, 51 were known to have medicinal values, accounting for $89.5 \%$, some of which had multiple medicinal effects, such as the leaves of Alpinia abundiflora, Aspidistra zongbayi, Indocalamus tessellatus Phrynium capitatum, and Piper sarmentosum (Table 1). In total, 23 types of medicinal values were found (Fig. 5). Heat-clearing, detoxification, and rheumatism treatment were the three most dominant medicinal functions, with 31 (54.4\%), 22 (38.6\%), and $13(22.8 \%)$ species of ZLs, respectively, followed by inflammation-diminishing, hemostasis, and diuresis, with 12, 12, and 9 species of ZLs, respectively. Heat-clearing is a concept in traditional Chinese medicine (TCM). In TCM, heat is one of the main pathogenic factors which could cause disturbance in human body, such as oral ulcer and urethritis [50, 51]. Besides, there were 6, 4, and 3 species of ZLs used to relieve pain, alleviate emesis and reduce hyperglycemia, respectively. The areas where people characterized the medicinal values of ZLs were listed in Additional file 1: Table S1.

Based on our analysis, 28 of 31 species of ZLs with heat-clearing function, 20 of 22 with detoxifying effect, and 10 of 13 with rheumatism-treating value are widely used as traditional ZLs in regions located in Southern

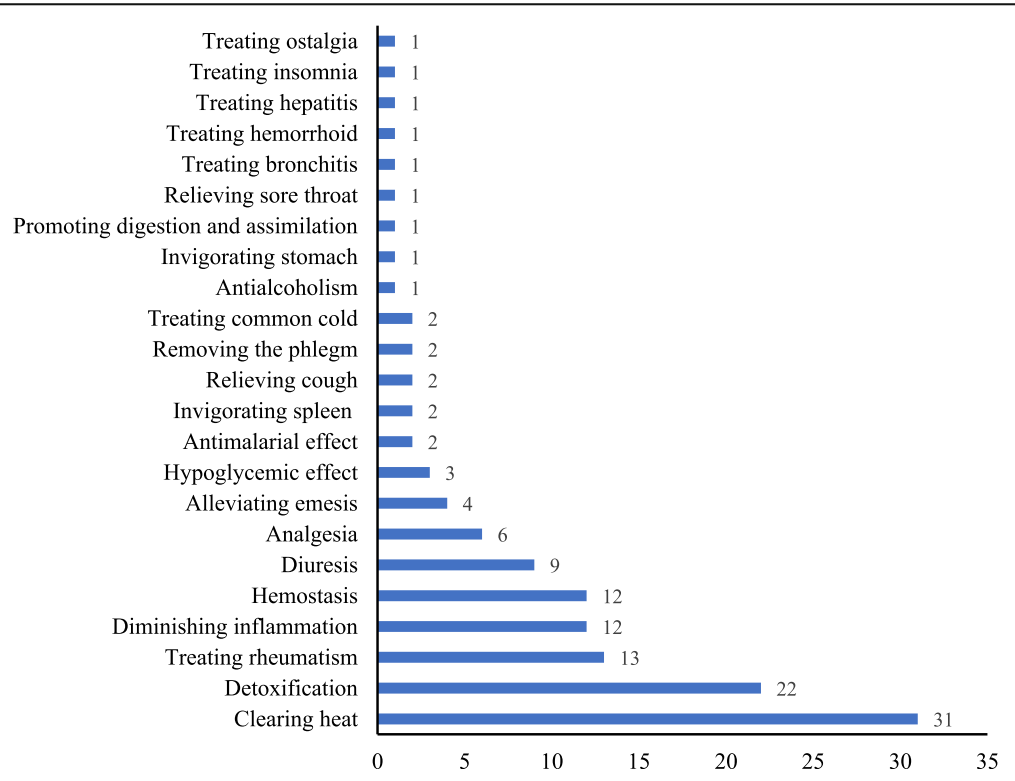

Fig. 5 Medicinal values of ZLs 
China (Tables 1 and 3). The Dragon Boat Festival is celebrated when the weather is hot and humid especially in the south of China. The climatic environment with high humidity and temperature could contribute to the extensive production of internal heat (in TCM) in our body, and functional deficiency of liver and kidney [52]. Thus, $z o n g z i$ wrapped by the plant leaves with medicinal functions of heat elimination, detoxification, and rheumatism treatment may help people compromise internal heat and wetness, and then prevent related ailments.

Importantly, among the nine species of ZLs which were useful for diuresis, all species also had a heat-clearing function; within 22 with detoxifying function, 19 possessed a medicinal value of clearing heat. In addition, five species were also involved in the inflammationdiminishing effect among six species with analgesia value. Further studies should be conducted to clarify the relationship, which will be beneficial to the theoretical constructions for TCM [34].

Nowadays, diabetes mellitus, a common metabolic and endocrine disorder, has posed a great threat to human health globally [53]. Insulin and some synthetic diabetic agents which have certain side effects are still the main drugs used for diabetic therapy clinically [54]. Searching for natural and effective compounds to treat diabetes is still greatly needed [55]. It is worthwhile to mention that people believe the leaves of Saccharum officinarum, Terminalia catappa, and Zea mays have hypoglycemic effects. It was reported that the polysaccharides from the leaves of $S$. officinarum and aqueous extracts of $T$. catappa leaves had significant hypoglycemic activities on mice $[56,57]$, which supported the medicinal value of traditional knowledge. Even though the polysaccharides from corn silk and the phenolic extract of corn seeds were found to have bioactivity for hypoglycemia management [58-60], the hypoglycemic effects of corn leaves have not been reported yet. Thus, further studies should be conducted to evaluate the hypoglycemic properties of corn leaves.

Malaria caused by Plasmodium parasites, such as $P$. falciparum and P. vivax, is one of the most serious diseases in the world [61]. Although combination therapies with Artemisinin-based drugs are effective to remedy malaria globally, parasites with artemisinin resistance have been emerged in Africa [62, 63]. Hence, continuing investments in the development of new medicines remain urgent [64]. According to our surveys, the ZLs of Musa wilsonii and Piper sarmentosum possessed antimalarial activities. It is reported by Rahman et al. [65] that methanol and chloroform extracts from P. sarmentosum showed significant antimalarial effects, supporting our investigated plant knowledge. However, to date, the antimalarial activity as well as the chemical constituents of the leaves of $M$. wilsonii have not been clarified.
Future research deserves to be conducted to determine its potential ability against malaria.

\section{Other functions of ZLs}

In addition to the functions of flavor contribution, antiseptic activity and medicinal effects, some species of ZLs also have other functions. On the basis of our surveys, the edible value of the leaves of Piper sarmentosum has been recognized by local people in Southern China, especially in Guangdong and Guangxi provinces. The leaves from this species could serve as delicious seasonings that could be added into dishes, such as soup, riversnail cuisine, and beef patty. In Thailand, the leaves of $P$. sarmentosum are traditionally used as food as well [66]. In Lingshui Li Autonomous County of Hainan Province, the leaves of Pandanus austrosinensis not only could be used to wrap zongzi, but also could be used for the weaving of straw mats, hats and baskets, the constructions of house barriers, and even the mythical functions of frightening and expelling the evils. Interestingly, it was told by the local people in Shagang Village that the leaves of $P$. austrosinensis could be used as fences to prevent intruders because of its spiny leaves. Consequently, the leaves of $P$. austrosinensis provide convenience for people both materially and mentally. People in Cimuchuan Village (Dazhuangke Township, Yanqing County, Beijing) had found that the leaves of Tilia tuan could make more contribution to both the sweet taste and spongy texture of zongzi when compared with the leaves of Phragmites australis.

\section{Effects of ZLs on food safety}

According to our interviews, people generally believe that traditional ZLs are environmental-friendly, non-toxic, and good for human health. However, based on the literature studies [67-70], the ZLs of Corchorus capsularis and Vernicia fordii may have potential health risks.

The ZLs of C. capsularis are prevalent in the northern part of Guangxi Province such as Yongfu County. Although the current research showed that the plant species of C. capsularis possessed various pharmacological effects such as antioxidant, anti-inflammatory and antipyretic activities, it is considered a toxic plant due to the presence of cardioactive constituents contained, such as Corchoroside A and B in the leaves and seeds [67]. It was reported that Corchoroside A and B from leaf extracts exhibited toxicity to cats with a lethal dose of $0.053-0.0768$ and $0.059-0.1413 \mathrm{mg} / \mathrm{kg}$, respectively [68]. In addition, after dietary exposure to $C$. capsularis leaves, cattles can suffer from the functional depression of respiratory and vasomotor center, and even death [69]. We should be cautious when using the leaves of $C$. capsularis as packaging materials, and the accessible frequency of zongzi with $C$. capsularis leaves should be 
limited until we better understand its potential toxicity to humankind.

It is prevalent to use the leaves of $V$. fordii to wrap zongzi in Hunan and Sichuan provinces in China. Even though the roots, leaves, and fruits of $V$. fordii have been traditionally used to remedy ailments including sore throats, respiratory illnesses, constipation, and diuresis in East Asian folk medicine [71, 72], it was reported that the whole plant of $V$. fordii had some toxicity especially its seeds [70]. Consequently, the potential effects of the leaves of $V$. fordii on our human health should not be ignored.

Despite the fact that these two species of ZLs we found may have a potential threat to people's health, no acute poisoning events have been reported in folk history. Herein, we speculate that the toxic constituents may be destroyed or transferred to non-toxic components by steaming or boiling with high temperature, or the contents of poison-active compounds are not enough to cause acute intoxication. Nevertheless, despite the long history usage of traditional ZLs, studies concerning their effects on human health are greatly lacking. Further studies are urgently necessary in order to guarantee food security for the sake of our human health. The future investigations can focus on toxicological assessments of ZLs, such as acute and subacute tests, and the possibility of detoxification under zongzi-making processes.

\section{Potential impact of commercialization on traditional ZLs} Nowadays, 12 species of ZLs have been commercialized and are easily accessed via online shopping stores: the leaves of Alpinia zerumbet, Indocalamus tessellatus, Musa basjoo, Musa nana, Nelumbo nucifera, Phragmites australis, Phrynium capitatum, Piper sarmentosum, Quercus dentata, Sterculia nobilis, Vernicia fordii, and Zea mays. According to our interviews, some species of traditional ZLs including Cocos nucifera used in Wenchang City of Hainan Province, Tilia tuan used in Yanqing County of Beijing, and Zizania latifolia used in Suzhou City of Jiangsu Province, had been threatened by commercialized ZLs such as the leaves of I. tessellatus and $P$. australis, because of their low price, good quality, and easily accessible advantages. The indivisible interconnections have been recognized between biological and cultural diversity, and the destruction of biodiversity can lead to the loss of associated culture [73]. Thus, once the traditional ZLs used in extremely limited regions, such as the threatened ZLs of T. tuan and Z. latifolia, which, according to our surveys, are only utilized by people in Beijing and Suzhou City, respectively, have been substituted by other common leaves, they are likely to be lost irreversibly, along with related culture including associated traditional knowledge. The effects of ecommerce and commercialized ZLs on traditional ZLs should not be neglected. The variety of traditional ZLs in China may decrease, which could threaten the cultural diversity of zongzi or the Dragon Boat Festival to some extent. However, the specific influence of commercialized ZLs still needs to be further determined.

\section{Conclusion}

The plant species used for wrapping zongzi, the traditional food for celebrating the Dragon Boat Festival in China, depending on regional traditions and local plant species. Using various species of ZLs reflects the fact that Chinese people make good use of the local materials in their regions. A total of 57 plant species (38 genera and 18 families) were documented and identified, among which the leaves of Indocalamus spp. and Phragmites australis are the most dominant in Southern and Northern China, respectively. There are some widespread folk legends about ZLs, which culturally reveal the origins of using plant leaves to wrap zongzi. With the traditional uses of ZLs, Chinese people have achieved a wealth of traditional botanical knowledge, particularly in flavor contribution, antiseptic functions, and medicinal effects, some of which are supported by current scientific research. However, some species of traditional ZLs such as the leaves of $C$. capsularis and $V$. fordii may pose a potential threat to human health. Further studies remain to be conducted to comprehensively evaluate these traditional uses. At present, in some areas, there is a potential possibility that some traditional ZLs, including the ZLs of Cocos nucifera and Tilia tuan, as well as the most ancient ZLs of Zizania latifolia, are threatened and could be replaced by the commercialized ZLs, such as the leaves of Indocalamus tessellatus and Phragmites australis. However, the potential impact of commercialization on traditional ZLs still needs to be studied. Our study highlights the ethnobotanical knowledge surrounding ZLs, and could provide important clues for their further studies.

\section{Supplementary information}

Supplementary information accompanies this paper at https://doi.org/10. 1186/s13002-019-0339-7.

Additional file 1: Table S1. The investigation areas (county level) where people are familiar with the functions of ZLs.

\section{Acknowledgements \\ We greatly appreciate the local people in the investigated areas who provided valuable information about zongzi leaves. We are also grateful to Eric Miller from the University of California at San Francisco who helped to edit the English.}

\section{Authors' contributions}

LCL and LB conceived and designed the study. LFK conducted the data collection. $L F K, L B S$, and $L B$ integrated the inventory and its analysis. $L C L$ and LB identified the plant species. LFK wrote the draft manuscript. All authors read and approved the final manuscript. 


\section{Funding}

This work was supported by the National Natural Science Foundation of China (31761143001, 31870316, and 31161140345), Key Laboratory of Ethnomedicine (Minzu University of China) of Ministry of Education of China (KLEM-ZZ201906 and KLEM-ZZ201806), Biodiversity Survey and Assessment Project of the Ministry of Ecology and Environment of China

(2019HJ2096001006), Jiansheng Fresh Herb Medicine R\&D Foundation (JSYY20190101-043), Minzu University of China (Collaborative Innovation Center for Ethnic Minority Development and YLDXXK201819), and Ministry of Education of China and State Administration of Foreign Experts Affairs of China (B08044).

\section{Availability of data and materials}

All data generated or analyzed during this study are included in this published article and its supplementary information files.

\section{Ethics approval and consent to participate}

Not applicable.

\section{Consent for publication}

Not applicable.

\section{Competing interests}

The authors declare that they have no competing interests.

\section{Author details}

${ }^{1}$ Key Laboratory of Ethnomedicine (Minzu University of China), Ministry of Education, Beijing 100081, China. ${ }^{2}$ College of Life and Environmental Sciences, Minzu University of China, Beijing 100081, China. ${ }^{3}$ School of Life Science, Yunnan University, Kunming 650091, China. ${ }^{4}$ Kunming Institute of Botany, Chinese Academy of Sciences, Kunming 650201, China.

\section{Received: 8 August 2019 Accepted: 31 October 2019} Published online: 11 December 2019

\section{References}

1. Zhang ZY. A brief account of traditional Chinese festival customs. J Pop Cult. 1993;27(2):13 https://doi.org/10.1111/j.0022-3840.1993.1354684.x.

2. Liu PB. The origin and inheritance of zongzi of the Dragon Boat Festival. Lantai World. 2013;10:118-9.

3. Wu YL. Comparison of folk culture of the Dragon Boat Festival in China and Japan. J Beifang Univ Nationalities. 2011;2:58-62.

4. Maite L, Cltlalli L-B, Sergio A, Melissa C. The plant leaves used to wrap tamales in the Mexican state. Econ Bot. 2017;71(4):374-9 https://doi.org/10. 1007/s12231-017-9396-9.

5. Dogan Y, Nedelcheva A, Łuczaj Ł, Drăgulescu C, Stefkov G, Maglajlić A, et al. Of the importance of a leaf: the ethnobotany of sarma in Turkey and the Balkans. J Ethnobiol Ethnomed. 2015;11(1):26 https://doi.org/10.1186/ s13002-015-0002-X.

6. Xu TR, Zhang RQ. Comments on the zongzi during the Dragon Boat Festival. China Food. 2008;12:6-8.

7. Ge W, Li Q. Studies on the origin, classification, preparation and culture of zongzi. J Sichuan Tourism Univ. 2016;6:15-8.

8. Zhu YJ, Li MY, Feng XX. Investigation on the quality of quick-freeze steamed rice dumpling leaf. Sci Technol Food Ind. 2008;5:142-3.

9. Zong LX, Mao W, Xiao QM, Ma LP, Li WQ. Preliminary study on the development and application of corn leaves in the processing of zongzi. Sci Technol Food Ind. 2006;27(4):136-8.

10. Li AP, Zheng SH, Cao QM, Fu YF. Study on the processing technology of green protection of zongzi leaves. Food Ind Technol. 2006;2:115-7.

11. Siracusa $V$, Rocculi P, Romani S, Dalla RM. Biodegradable polymers for food packaging: a review. Trends Food Sci Tech. 2008;19(12):634-43 https://doi. org/10.1016/j.tifs.2008.07.003.

12. Davis $\mathrm{G}$, Song J. Biodegradable packaging based on raw materials from crops and their impact on waste management. Ind Crop Prod. 2006;23(2): 147-61 https://doi.org/10.1016/j.indcrop.2005.05.004.

13. Dogan Y, Nedelcheva A, Pieroni A. The diversity of plants used for the traditional dish sarma in Turkey: nature, garden and traditional cuisine in the modern era. Emir J Food Agric. 2017;29(6):429-40 https://doi.org/10. 9755/ejfa.2016-09-1238.
14. Ahmad SA, Askari AA. Ethnobotany of the Hawraman region of Kurdistan Iraq. Harvard Pap Bot. 2015;20(1):85-9 https://doi.org/10.3100/hpib.v20iss1. 2015.n8.

15. Ari S, Temel M, Kargıoğlu M, Konuk M. Ethnobotanical survey of plants used in Afyonkarahisar-Turkey. J Ethnobiol Ethnomed. 2015;11(1):84 https://doi. org/10.1186/s13002-015-0067-6.

16. Nacakcı FM, Dutkuner I. A study of ethnobotany in Kumluca (Antalya). Turk J For. 2018;19(2):113-9 https://doi.org/10.18182/tjf.421970.

17. Güneş F. An ethnobotany study in Enez Town from Edirne. Curr Pers MAPs. 2018;1(1):28-35.

18. Salazar C, Zizumbo-Villarreal D, Brush SB, Colunga-GarcíaMarín P. Earth ovens (píib) in the Maya lowlands: ethnobotanical data supporting early use. Econ Bot. 2012;66(3):285-97 https://doi.org/10.1007/s12231-012-9207-2.

19. Li R, Hu HB, Li XF, Zhang P, Xu YK, Yang JJ, et al. Essential oils composition and bioactivities of two species leaves used as packaging materials in Xishuangbanna. China. Food Control. 2015;51:9-14 https://doi.org/10.1016/j. foodcont.2014.11.009.

20. Alexiades MN, Sheldon JW. Selected guidelines for ethnobotanical research: a field manual. New York: Botanical Garden; 1996.

21. Long CL. Wild plant resources: Science Press; 2015

22. Long CY. The fragrant zongzi during the Dragon Boat Festival. Beijing Arch. 2011;6:46.

23. Cai JQ. Dragon Boat Festival is the customary evolution and cultural significance of Qu Yuan. Soc Sci Hubei. 2016;1:115-24.

24. Ma MD. Zhu Yuanzhang's discrimination to Semu people. Res Hui. 2006;1: 98-102.

25. Victório C, Arruda R, Riehl C, Lage C. Leaf volatiles and secretory cells of Alpinia zerumbet (Pers.) Burtt et Smith (Zingiberaceae). Nat Prod Res. 2011; 25(10):939-48 https://doi.org/10.1080/14786419.2010.514575.

26. Shanmugam PV, Yadav A, Chanotiya C. Enantiomer differentiation of key volatile constituents from leaves, stems, rhizome and flowers of cultivated Hedychium coronarium Koenig from India. J Essent Oil Res. 2015;27(2):101-6 https://doi.org/10.1080/10412905.2014.987929.

27. Cui J. Flavonoids and volatile components from Indocalams leaves [D]. Chinese Academy of Forestry: Beijing; 2011.

28. Yu AN, Wang FS, Yang CH, Zeng DH, Dan YM. Study of flavour components of Ruoye (Indocalamus tessellatus). Fine Chemicals. 2002;19(4):201-3.

29. Yang CH, Liu YX, Zhai WY, Yu AN. Study on organoleptic compounds of Musa acuminata in Enshi county. Food Sci Technol. 2007;9:139-41.

30. Fu QB, Cai WR, Xie LL, Pan H, Wu XY, Cao X. Headspace solid-phase microextraction-GC/MS analysis of Lotus leaf aroma components. J Anhui Univ Technol Sci. 2017;32(1):24-8.

31. Seo WH, Baek HH. Characteristic aroma-active compounds of Korean perilla (Perilla frutescens Britton) leaf. J Agr Food Chem. 2009;57(24):11537-42 https://doi.org/10.1021/jf902669d.

32. Zhang LN, Meng XX, Gao Q, Guo LY, Yang GD, Yang FL. Chemical constituents of the volatile oil from fresh and dried Quercus dentata Thunb. leaves and the effect of $\beta$-glucosidase on enhancing its aroma. Nat Pro Res Develop. 2019;31(6):1062-9.

33. Mau JL, Ko PT, Chyau CC. Aroma characterization and antioxidant activity of supercritical carbon dioxide extracts from Terminalia catappa leaves. Food Res Int. 2003;36(1):97-104 https://doi.org/10.1016/S0963-9969(02)00114-X.

34. Jin B, Liu YJ, Xie JX, Luo BS, Long CL. Ethnobotanical survey of plant species for herbal tea in a Yao autonomous county (Jianghua, China): results of a 2-year study of traditional medicinal markets on the Dragon Boat Festival. J Ethnobiol Ethnomed. 2018;14(1):58 https://doi.org/10.1186/s13002-018-0257-0.

35. Appendini $P$, Hotchkiss JH. Review of antimicrobial food packaging. Innov Food Sci Emerg. 2002;3(2):113-26 https://doi.org/10.1016/S14668564(02)00012-7.

36. Koketsu M, Kim M, Yamamoto T. Antifungal activity against food-borne fungi of Aspidistra elatior Blume. J Agr Food Chem. 1996;44(1):301-3 https:// doi.org/10.1021/jf950273r.

37. Figueira C, Santos JM, Povoas FTX, Viana MDM, Moreira MSA. Assessment of antimicrobial and cytotoxic activities of crude extracts from Cocos nucifera Linn. J Chem Pharm Res. 2016;8(8):276-82.

38. Li YF, Dai Y, Li JJ. Comparison of scavenging DPPH free radical and restraining bacteria of Indocalamus latifolius leaf's extracts. Food Sci Technol. 2010;35(4):174-7.

39. Zhang H, Lin H, Sheng E, Li L, Hu S, Mao S. Study on antibacterial activity of extracts from Indocalamus tessellatus leaves. J Zhejiang For Sci Technol. 2010;30(3):38-41. 
40. Li XC. Chemical composition and antimicrobial activity of the essential oil from the leaf of Magnolia officinalis. Food Sci Technol. 2013;38(1):271-5.

41. Meenashree B, Vasanthi V, Mary RNI. Evaluation of total phenolic content and antimicrobial activities exhibited by the leaf extracts of Musa acuminata (banana). Int J Curr Microbiol App Sci. 2014;3(5):136-41.

42. Zeid A. Chemical and biological study of the leaves of some Musa species. Egyptian J Pharm Sci. 1998;39(6):379-98.

43. Kumar D, Kumar S, Kumar S, Singh J, Sharma C, Aneja KR. Antimicrobial and preliminary phytochemical screening of crude leaf extract of Pandanus odoratissimus L. Pharmacol Online. 2010;2:600-10.

44. Xu W, Guo HB, Shao R, Yu XH, Ma L, Yun Z. Study on antibacterial activity and antioxidant activity of total flavonoids from reed leaf. J Anhui Agr Sci. 2010;38(29):16158-61.

45. Taweechaisupapong S, Singhara S, Lertsatitthanakorn P, Khunkitti W. Antimicrobial effects of Boesenbergia pandurata and Piper sarmentosum leaf extracts on planktonic cells and biofilm of oral pathogens. Pak J Pharm Sci. 2010;23(2):224-31 https://doi.org/10.1038/npp.2010.22.

46. Fernandez L, Daruliza K, Sudhakaran S, Jegathambigai R. Antimicrobial activity of the crude extract of Piper sarmentosum against methicilinresistant Staphylococcus aureus (MRSA), Escherichia coli, Vibrio cholera and Streptococcus pneumoniae. Eur Rev Med Pharm Sci. 2012;16(3):105-11 https://doi.org/10.4103/0250-474X.107085.

47. Yun JW, Yoo MY, Park BK, Lee MK, Oh DH. Antimicrobial effect of ethanol extracts of Quercus spp. against foodborne pathogens. J Korean Soc Food Sci. 2004;33(3):463-8 https://doi.org/10.3746/jkfn.2004.33.3.463.

48. Kusuma S, Soraya R, Indah F, Resmi M. Study on the antibacterial activity of fruit extracts of Klutuk Banana (Musa balbisiana colla) against Shigella dysenteriae ATCC 13313. Asian J Pharm Clin Res. 2017;10(7):220 https://doi. org/10.22159/ajpcr.2017.v10i7.18561.

49. Wei JF, Zhang Q, Zhao L, Kang WY. Antimicrobial activity of Musa Basjoo in vitro. Chinese J Exp Tradit Med Formulae. 2010;16(17):69-71.

50. Tse TW. Use of common Chinese herbs in the treatment of psoriasis. Clin Exp Dermatol. 2003;28(5):469-75 https://doi.org/10.1046/j.1365-2230.2003.01322.x

51. Muluye RA, Bian Y, Alemu PN. Anti-inflammatory and antimicrobial effects of heat-clearing Chinese herbs: a current review. J Tradit Complement Med. 2014:4(2):93-8 https://doi.org/10.4103/2225-4110.126635.

52. Wen DL, Su J. Study on the relationship between geographical climate and physical characteristics of Lingnan areas and warm disease. Chinese J Basic Med Tradit Chinese Med. 2010;16(4):276-7.

53. Marx J. Unraveling the causes of diabetes. Science. 2002;296(5568):686-9 https://doi.org/10.1126/science.296.5568.686.

54. Raz I, Eldor R. Rational therapy for diabetes: early recognition of adverse effects and avoidance of disruptive false alarms. Diabetes. 2012;28(4):321-4 https://doi.org/10.1002/dmrr.2265.

55. Wang J, Ha TKQ, Shi YP, Oh WK, Yang JL. Hypoglycemic triterpenes from Gynostemma pentaphyllum. Phytochemistry. 2018;155:171-81 https://doi. org/10.1016/j.phytochem.2018.08.008.

56. Hou XT. Research on chemical constituents and pharmacodynamics of sugarcane leaves [D]. Guangxi: Guangxi Medical University; 2014.

57. Ahmed SM, Swamy V, Gopkumar P, Dhanapal R. Anti-diabetic activity of Terminalia catappa Linn. leaf extracts in alloxan-induced diabetic rats. Iran J Pharmacol Ther. 2005;4(1):36-9.

58. Ma YQ, Wang X, Gao S. Hypoglycemic activity of polysaccharides from sweet corncob on streptozotocin-induced diabetic rats. J Food Sci. 2017; 82(1):208-13 https://doi.org/10.1111/1750-3841.13554.

59. Adrian GM, Ana Maria QV, Claudia F, Kalidas S, Lena GR. Potential of Chilean native corn (Zea mays L.) accessions as natural sources of phenolic antioxidants and in vitro bioactivity for hyperglycemia and hypertension management. J Agr Food Chem. 2013;61(46):10995-1007 https://doi.org/10. 1021/jf403237p

60. Sabiu S, O'neill FH, Ashafa AOT. Kinetics of a-amylase and a-glucosidase inhibitory potential of Zea mays Linnaeus (Poaceae), stigma maydis aqueous extract: an in vitro assessment. J Ethnopharmacol. 2016;183:1-8 https://doi. org/10.1016/j.jep.2016.02.024

61. Hay SI, Guerra CA, Tatem AJ, Noor AM, Snow RW. The global distribution and population at risk of malaria: past, present, and future. Lancet Infect Dis. 2004;4(6):327-34 https://doi.org/10.1016/S1473-3099(04)01043-6.

62. Tun KM, Imwong M, Lwin KM, Win AA, Hlaing TM, Hlaing $T$, et al. Spread of artemisinin-resistant Plasmodium falciparum in Myanmar: a cross-sectional survey of the K13 molecular marker. Lancet Infect Dis. 2015;15(4):415-21 https://doi.org/10.1016/S1473-3099(15)70032-0.
63. Lu F, Culleton R, Zhang M, Ramaprasad A, Von Seidlein L, Zhou H, et al. Emergence of indigenous artemisinin-resistant Plasmodium falciparum in Africa. New Engl J Med. 2017;376:991-3 https://doi.org/10.1056/ NEJMc1612765.

64. Xue L, Shi DH, Harjani JR, Huang F, Beveridge J, Dingjan T, et al. 3, 3'Disubstituted 5, 5'-Bi (1, 2, 4-triazine) derivatives with potent in vitro and in vivo antimalarial Activity. J Med Chem. 2019;62(5):2485-98 https://doi.org/ 10.1021/acs.jmedchem.8b01799.

65. Rahman N, Furuta T, Kojima S, Takane K, Mohd MA. Antimalarial activity of extracts of Malaysian medicinal plants. J Ethnopharmacol. 1999;64(3):249-54 https://doi.org/10.1016/S0378-8741(98)00135-4.

66. Peungvicha $P$, Thirawarapan SS, Temsiririrkkul $R$, Watanabe $H$, Prasain JK, Kadota S, et al. Hypoglycemic effect of the water extract of Piper sarmentosum in rats. J Ethnopharmacol. 1998;60(1):27-32 https://doi.org/10. 1016/S0378-8741(97)00127-X

67. Al-Snafi AE. The contents and pharmacological importance of Corchorus capsularis-a review. IOSR J Pharm. 2016;6(6):58-63.

68. Tabassum T. Extraction, identification and estimation of caffeine and catechin from Corchorus capsularis leaves extract [D]. Chicago: East-West University; 2014

69. Zhang XQ. The poisoning of Corchorus capsularis in cattles. Chinese J Vet Med. 1997:7:39-40.

70. Smith JP Jr. Poisonous plants of the United States: a tabular summary. Bot Stud. 2017;67.

71. Ito Y, Yanase S, Tokuda H, Kishishita M, Ohigashi H, Hirota M, Koshimizu K. Epstein-Barr virus activation by tung oil, extracts of Aleurites fordii and its diterpene ester 12-0-hexadecanoyl-16-hydroxyphorbol-13-acetate. J Cancer Lett. 1983;18(1):87-95 https://doi.org/10.1016/0304-3835(83)90121-0.

72. Pencreach $G$, Jean $G$, Pina M, Robert V. An ultraviolet spectrophotometric assay for measuring lipase activity using long-chain triacyglycerols from Aleurites fordii seeds. Anal Biochem. 2002;303(1):17-24 https://doi.org/10. 1006/abio.2001.5427.

73. Pretty J, Adams B, Berkes F, Athayde S, Dudley N, Hunn E, et al. The intersections of biological diversity and cultural diversity: towards integration. Conserv Soc. 2009;7(2):100-12 https://doi.org/10.4103/09724923.58642

\section{Publisher's Note}

Springer Nature remains neutral with regard to jurisdictional claims in published maps and institutional affiliations.
Ready to submit your research? Choose BMC and benefit from:

- fast, convenient online submission

- thorough peer review by experienced researchers in your field

- rapid publication on acceptance

- support for research data, including large and complex data types

- gold Open Access which fosters wider collaboration and increased citations

- maximum visibility for your research: over $100 \mathrm{M}$ website views per year

At BMC, research is always in progress.

Learn more biomedcentral.com/submissions 